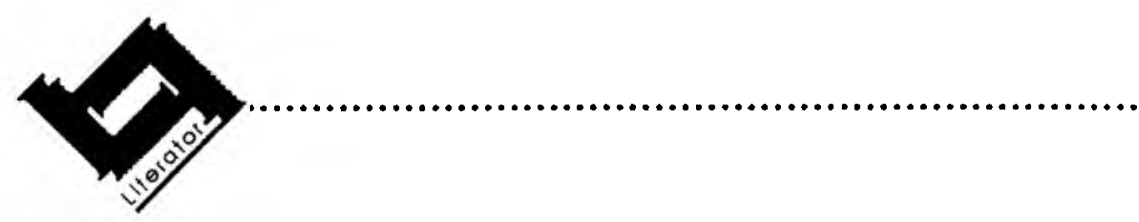

\title{
Ambivalence in the Christian poetry of C.S. Lewis
}

\author{
G.M. Smith \\ Department of English \\ Vista University Distance Education Campus \\ Vista University \\ PRETORIA \\ E-mail: smith-gm@acaleph.vista.ac,za
}

\section{Abstract}

\section{Ambivalence in the Christian poetry of C.S. Lewis}

This article examines the ambivalence expressed in certain of the explicitly Christian poems written by C.S. Lewis. As a writer his primary claim to fame is his Christian apologetics, in spite of the fact that he is well thought of in literary circles and produced several scholarly works. In the light of his considered Christian convictions, one would expect his poetry to voice a strong faith and confidence in God. However, somewhat ironically, certain of his poems reflect his struggles and doubts concerning faith in an intensely personal register. Nevertheless, in spite of his ambivalent feelings towards God, he retains the certainty that God is able to transcend his human frailty and difficulties. The problem of faith is relevant in our own time, and it therefore seems fitting that we should examine certain of C.S. Lewis's poems in commemoration of the centenary year of his birth.

\section{Introduction}

1998 marked the centenary of the birth of Clive Staples Lewis, who enjoyed immense popularity as a Christian writer in the middle part of this century, and who indeed continues to be read in our own time. It is primarily as a Christian apologist that Lewis is known, but there are other facets of the author's writing that deserve attention. Apart from his works of popular but intellectually muscular theology, Lewis was an English scholar of note who not only published critical works on such varied themes as medieval courtly love and aspects of Milton's work, but also produced a volume in the Oxford History of 
English Literature entitled English Literature in the Sixteenth Century Excluding Drama (1954). His main claim to fame is perhaps the stories meant for children of all ages in the Narnia series, of which The Lion, the Witch and the Wardrobe (1950) is the best known. Less often read are the space trilogy Out of the Silent Planet (1938), Perelandra (1943) and That Hideous Strength (1945) and his reinterpretation of the Cupid-Psyche myth under the title Till We Have Faces (1956). Lewis's versatility is evident, but it nevertheless comes as something of a surprise to find that he wrote good poetry as well. To mark the centenary of his birth, it seems fitting to consider a selection of poems that express certain of Lewis's struggles relating to his Christian faith, as it is apparent that the cultivation of an intellectually robust faith which did not degenerate into easy believism was the informing principle in all his writings.

A difficulty arises in any attempt to classify Lewis's poems. They cannot be classified chronologically because many were undated and they were only collected posthumously in 1964 from such varied sources as The Times Literary Supplement, Punch and The Spectator, their original publication spanning a period of about twenty years. Some of the poems in the collection are intrinsic to Lewis's allegorical work entitled The Pilgrim's Regress which was first published in 1933. The editor of the poems, who was Lewis's secretary, also included some of Lewis's work that had not been published before, possibly on account of its personal nature. This article will focus on certain of the poems that are overtly devotional in nature, and which voice the intellectual and emotional struggle to come to and sustain faith in the face of doubt. The resultant poetry is demanding but clear in the expression of its conviction that God understands and is able to transcend humankind's doubts and fears. It should be noted that the intense personal register and content of the poems make it difficult to separate Lewis the poet from the speaker in the works, but generally I have referred to the speaker in order to obviate confusion. Because Lewis's poetry is little-known and not readily accessible, the complete text of each poem is included to facilitate analysis.

\section{2. "Sweet Desire"}

In the poem entitled "Sweet Desire", the speaker expresses the difficulty of forming a correct concept of God in the light of erroneous preconceptions about Him:

These faint wavering far-travell'd gleams

Coming from your country, fill me with care. That scent,

That sweet stabbing, as at the song of thrush,

That leap of the heart - too like they seem

To another air; unlike as well

So that I am dazed with doubt. As a dungeoned man

Who has heard the hinge on the hook turning 
Often. Always that opened door

Let new tormentors in. If now at last

It open again, but outward, offering free way,

(His kind one come, with comfort) he

Yet shrinks, in his straw, struggling backward,

From his dear, from his door, into the dark'st corner,

Furthest from freedom. So, fearing, I

Taste not but with trembling. I was tricked before.

All the heraldry of heaven, holy monsters,

With hazardous and dim half-likeness taunt

Long-haunted men. The like is not the same.

Always evil was an ape. I know.

Who passes to paradise, within that pure border

Finds there, refashioned, all that he fled from here.

And yet ...

But what's the use? For yield I must,

Though long delayed, at last must dare

To give over, to be eased of my iron casing,

Molten at thy melody, as men of snow

In the solar smile. Slow-paced I come,

Yielding by inches. An yet, oh Lord, and yet,

- Oh Lord, let not likeness fool me again.

(Lewis, 1964:114)

The poem as a whole expresses the speaker's desire for an encounter with the reality of God rather than his own construct of Him. In keeping with the sense of the medieval prompted by the alliterative metre, Lewis uses the image of a prisoner incarcerated in a dungeon to speak of man's imprisonment in his own conception of what God is really like. The poem is distinctive in that it reflects an intensely personal register, which is unusual in Lewis's poetry. In the opening lines, the speaker, addressing God, expresses the awakening of his longing to experience $\mathrm{Him}$ in reality in terms of a strange desire for a distant country. This image contains echoes of Homer's Odyssey and Tennyson's "Ulysses" and comes to function as a symbol of the speaker's longing for God. It also expresses a Sehnsucht and longing for the Other, a central concern in Lewis's writing, which he suggested was common to all humans and which he maintained argued the fact of God's existence.

The fact that the speaker perceives the "gleams" from the distant country as being "far-travelled" and "faint" indicates the tremendous distance between God and the concept the speaker in the poem has of Him. His ambivalent feelings towards God are expressed in the paradox "sweet stabbing", and the assertion that the "gleams" "fill [him] with care". He admits that these "gleams" are "too like" "another air", the term "another air" referring to his present mode of existence. The speaker's ambivalence is underlined when he stresses that the 
"gleams" are "unlike as well", as does his assertion that he is "dazed with doubt".

The speaker likens himself in his "doubt" to a "dungeoned man/Who has heard the hinge on the hook turning/Often". Lewis would have been aware of the fact that some of the Counter-Reformation priests and poets employed the dungeon image (Secker, 1982:122-141), and his use of it adds a Renaissance dimension and echoes the concern of these people with the search for ultimate religious truth in the face of difficulties. The dungeon image is developed in lines $6 \mathrm{~b}$ to 14. Lewis's style here is evocative of Gerard Manley Hopkins's poetry, not only in the use of alliterative metre, but also in the unusual sentence construction. It also reflects the tone of Hopkins's desolate sonnets, reiterating the ambivalent feeling towards God which is one that has been experienced by Christians through the ages.

Apart from their similarity to Hopkins's poetry, lines $6 \mathrm{~b}$ to 14 also contain many Biblical concepts and allusions. The possibility that the prisoner's saviour from the dungeon may be Christ is suggested by the compassion of Christ, evoked in the epithet "his kind one", and also by the reference to him as "his door", possibly alluding to John 10:9, in which Jesus asserts that he is the door. There are suggestions here too of Revelation 3:20 (KJV): "[b]ehold, I stand at the door and knock: if any man hear my voice and open the door, I will come in to him and sup with him, and he with me". The conviction that the speaker may be referring to Christ is strengthened by the poet's admission that he "shrinks" away from his rescuer "into the dark'st corner", which speaks of his apparent reluctance to embrace the concept of God as embodied in Christ, who in John 8:12 referred to himself as the light of the world. The light/darkness imagery is also used in the conventional religious sense to speak of spiritual illumination.

The phrase "in his straw" is very apt as part of the dungeon image, but it also functions as a symbol for humankind's inability to apprehend the reality of God. The phrase "in his straw" resonates with such Biblical quotations as Isaiah 42:3 (KJV): "A bruised reed shall he not break, and the smoking flax shall he not quench", and Matthew 12:20 in which Jesus quotes the Isaiah reference in relation to himself. By using the dungeon image the speaker is therefore obliquely asserting that in Christ man can experience a true representation of God in spite of his weakness of perception. Christ is seen as the one who can release the speaker from the prison house of his own constructs of God.

The speaker personifies his previous concepts of God as "tormentors", which suggests that he has hoped they would bring him spiritual insight, only to find that they have disappointed him. He expresses the effect that these "tormentors" have had on him in lines $14 \mathrm{~b}$ to 19 . The speaker refers to his "tormentors" as "all the heraldry of heaven", which suggests that they are symbols of heaven and may have represented it in a coat of arms, or are merely announcing its coming 
and are not the real thing. The paradox "holy monsters" conveys ambivalence: previous conceptions of God are "holy" because in some way they speak of Him, and yet they are "monsters" in that they are a distortion of the truth. The terse statement: "The like is not the same" is stressed by its position at the end of the line, and the speaker emphasizes that the counterfeit may copy aspects of reality in the metaphor "[a]lways evil was an ape". The speaker is thus asserting that his earlier constructs of God have been evil because they have counterfeited the truth, even while containing elements of it. This parallels Lewis's belief that the major religions of the world faithfully reflect some aspects of ultimate truth in their myths but that Christianity is the only religion in which "myth became fact" in the incarnation of Christ: "the heart of Christianity is a myth which is also a fact" (Lewis, 1970:6)

The speaker asserts that the person "who passes to paradise", experiences that what he has feared and "fled from" in this life, he encounters in a different form, "refashioned", there. Ironically, "paradise" does not here refer to some future existence, but rather to the experience of a true vision of Christ in the present The term "refashioned" may also suggest Christ's resurrection body, as does the reference to "paradise". The speaker may be positing that often a true concept of God is that from which we may shrink, only to fmd that an apprehension of the living, resurrected Christ in our present existence transforms our ideas of what God is like.

In A Grief Observed Lewis (1961:52) expresses his belief that some of our concepts of God need to undergo revision: "[i]mages of the Holy easily become holy images - sacrosanct. My idea of God is not a divine idea. It has to be shattered time after time. He shatters it Himself. $\mathrm{He}$ is the great iconoclast. Could we not almost say that this shattering is one of the marks of His presence?" The poem "Sweet Desire" may be considered as a poetic embodiment of this conviction of Lewis's.

The speaker in the poem echoes Lewis's belief that true concepts or images of God find their culmination in an acceptance of Christ as His incarnation. However, he makes it plain that such an acceptance is not easily embraced. The individual's rigidity regarding his perception of God, his "iron casing", has to be abandoned and he has to become pliable and "molten" in the hands of the divine Potter referred to in Jeremiah 18:8 and Romans 9:21 or the refiner of Malachi 3: 2-3. This concept of fluidity in the acceptance of new ideas is reinforced by the simile "as men of snow/In the solar smile", with the phrase "solar smile" carrying connotations of divine favour and compassion.

The speaker emphasizes his struggle to emerge from the dungeon of earlier concepts of God and to subdue his self-will when he insists that he comes "slowpaced" and "yielding by inches". The poem concludes with an impassioned plea, directed to God, whom he addresses as "Lord", which implies submission, that 
he may not be "fooled" once more by "likeness". At a first reading one may be inclined to think that the speaker is expressing doubts about the objectivity of his Christian vision. However, the plea that he may not be fooled "again" can be regarded as an indication of his tremendous need for an authentic vision of God, and not as a reflection on the authenticity of his experience.

The poem as a whole may therefore be said to deal with the theme of appearance and reality, with particular reference to religious experience, and voices the difficulties that are inherent in such experience. Lewis has fused such diverse elements as a Renaissance mood and imagery, a similarity to Hopkins's poetry, in style as well as in subject matter and tone, and a plethora of Biblical concepts and allusions to convey the spiritual struggle for a true apprehension of the divine.

\section{3. "The Naked Seed"}

A belief in the objective reality of God, who is conceived by the poet to stand separate from humankind whilst maintaining a constant interest in its welfare, is admirably portrayed in the sentiments expressed in the poem entitled "The Naked Seed". In this work, in contrast to the poem "Sweet Desire", the speaker laments his lack of longing for God and the absence of desire for fellowship with Him:

My heart is empty. All the fountains that should run

With longing, are in me

Dried up. In all my countryside there is not one

That drips to find the sea.

I have no care for anything thy love can grant

Except the moment's vain

And hardly noticed filling of the moment's want

And to be free from pain.

Oh, thou that art unwearying, that dost neither sleep

Nor slumber, who didst take

All care for Lazarus in the careless tomb, oh keep

Watch for me till I wake.

If thou think for me what I cannot think, if thou

Desire for me what I

Cannot desire, my soul's interior Form, though now

Deep-buried, will not die,

- No more than the insensible dropp'd seed which grows

Through winter ripe for birth

Because, while it forgets, the heaven remembering throws

Sweet influence still on earth,

- Because the heaven, moved moth-like by thy beauty, goes

Still turning round the earth.

(Lewis, 1964:117) 
The varying line lengths create a jerky, uneven effect, which, combined with the rigid rhyme scheme, reflects the speaker's ambivalent feelings towards God. He is aware of his own spiritual barrenness, which is emphasized by the position of the phrase "[d]ried up" at the beginning of a line. This spiritual dryness echoes one of Hopkins's themes, which is encapsulated in the final line of "Justus quidem tu es" (Hopkins, 1953:67): "[m]ine, O thou lord of life, send my roots rain". A Renaissance view of the same idea is evoked in Ignatius of Loyola's comments on the desolation occasioned by a sense of spiritual aridity as expressed in the Spiritual Exercises (Puhl, 1951:142). There is also a modern parallel in the image of aridity and spiritual sterility that is explored at length in T.S. Eliot's "The Wasteland" (Eliot, 1974:61-79). The resonances achieved by Lewis's image of dryness thus reinforce a sense of the timelessness and recurrence of the experience of spiritual drought throughout the ages.

The speaker here refers to his soul as land in which the "fountains" of "longing" have "dried up", and there is not even "one" that "drips to find the sea". As before, the poet is writing on an overtly devotional theme, drawing from a wide range of Christian sources. The image of God as the sea is one which is common in the mystical tradition. For example, St. Catherine of Siena (1347-1380) prays to God: "Thou, Eternal Trinity, art a sea so deep that the more I enter therein, the more I find ..." (Anderson, 1996:181). The "fountains" and water imagery which Lewis has employed invert Biblical allusions in order to voice the poet's perception of his lack of longing for God. The water imagery suggests Jesus' pronouncement in John 7:38 that rivers of living water would flow from the innermost being of those who believe in Him. There is also the implication that the speaker is not experiencing the contentment of being led "by still waters" which is referred to in Psalm 23:2. By inverting these allusions to express the lack he experiences, the speaker is drawing attention to the fact that he is spiritually dry. He realizes that any longings for God that he may have are in order that his own wants and desires may be satisfied: "the moment's vain/And hardly noticed filling of the moment's want/And to be free from pain".

After confessing his self-centredness, the speaker pleads with God to "keep watch" for him, supposing that his present state is a temporary one of sleep or inactivity:

Oh, thou that art unwearying, that dost neither sleep

Nor slumber, who didst take

All care for Lazarus in the careless tomb, oh keep

Watch for me till I wake.

The reference to God as the One who neither "sleep[s] nor slumber[s]," is an allusion to Psalm 121.4. The poet thus contrasts his state with that of God: he is inert, while God remains eternally alert. This is an implicit statement of the "otherness" of God, and His transcendence in the face of human weaknesses and 
qualities. The speaker asserts that it was God who cared for Lazarus in the "careless tomb", alluding to the Gospel account of the raising of Lazarus from the dead in John 11:11-46. The assumption here is that, just as Christ raised Lazarus physically, so he will also bring spiritual life to the speaker in the poem. The fact of restoration or resurrection is not doubted at all - he accepts it as a foregone conclusion, as evidenced by the clause "till I wake". The cycle of death and resurrection as expressed here anticipates the seed imagery which is to follow later in the poem.

The speaker's utter dependence on God is further highlighted when he asks God to take over his very thought processes in lines 13 to 22 . The speaker is thus abandoning himself completely to God. There is a marked contrast here to the emotions expressed in "Sweet Desire", in which the speaker struggles to yield himself to "his kind one", or Christ. The reference to the "interior Form" of his soul may suggest the philosophy reflected in Plato's concept of ideal forms, but it also evokes the idea of the germ of life which is inherent in apparently dead seeds. This evocation is reinforced by the direct reference to a "seed" in the following line. The fact that the speaker conceives of the seed as being "insensible" underlines his consciousness of his own lack of feeling. He suggests that, just as the seed is left "deep-buried" through the winter but shows signs of life in spring, so his "soul's interior Form" will eventually burgeon forth into life. This is not through its own power, because it "forgets" and lies dormant. As it is the effect of the sun's warmth that ensures the germination of the seed in the agricultural image, so it is God's care and grace which will bring the speaker spiritual life. Once again the poet is stressing the otherness of God, suggested by the term "heaven". The "seed" is "insensible" and "forgets", whereas "heaven remembers". The poem continually draws attention to the transcendence of God through the use of such contrasts.

The image of the dead seed is apt in its context, but it also abounds in Biblical allusions, particularly to the parables and sayings of Christ. One is immediately reminded of the cluster of agricultural parables recorded in Matthew 13:18-32 which includes the parables of the sower, the wheat and the tares, and the mustard seed. Perhaps the most powerful suggestion evoked by the speaker's comparison of his soul to a seed is that of the saying of Jesus in John 12:24 (KJV): "Verily, verily I say unto you, Except a corn of wheat fall into the ground and die, it abideth alone: but if it die, it bringeth forth much fruit". Paradoxically, the speaker sees that spiritual "death" is a vital part of life: if the seed does not "die" it cannot produce new life. There is thus the implicit suggestion that he will not only be restored to life, but will also bring forth fruit.

The conclusion of the poem is ironic. After asserting that it is "heaven remembering" that "throws sweet influence on earth", the speaker stresses that "the heaven" moves around "the earth". This is contrary to our knowledge of 
astronomy, as we know that the earth moves around the sun. This inversion may suggest several possibilities. It may point to humankind's lack of comprehension of reality, in that it is prone to think of itself as the centre of the universe, or it may suggest the concentration of God's love and care on our particular planet. Although references to God may be inferred from the use of the term "heaven", it here seems to represent the material universe. The phrase "moved moth-like by thy beauty" may therefore be said to evoke the doctrine that God is over and above the material universe, and exists independently of it. The suggestion is that the movement of "the heaven" is as a result of the influence exerted by God's "beauty" which symbolizes His inherent attributes, whereas the simile "moth-like" speaks of the fragility of the created order.

The poem as a whole expresses the speaker's utter dependence on God in the face of his spiritual aridity, while voicing his confidence that God will grant restoration to him, just as an apparently dead seed eventually sends forth shoots and grows. The use of the adjective "naked" in the poem's title stresses the fact that the speaker realizes that God sees the poverty and lifelessness of his spiritual state. He is aware of his own inadequacies and shortcomings with regard to his faith, but is confident of God's ability to deal with them and bring about spiritual restoration. The poem may be seen to be thematically related to Eliot's "Ash Wednesday" (Eliot, 1974:91-105) in that it explores the transcendence of God's mercy in the face of doubt and aridity on the part of the speaker.

\section{4. "Legion"}

While the poem "The Naked Seed" laments a lack of desire, the sonnet entitled "Legion" is an admission on the part of the speaker of the diversity of emotions and desires that he encounters within himself. The intensely personal register of the previous poems examined is sustained in an appeal to God:

Lord, hear my voice, my present voice I mean, Not that which may be speaking an hour hence (For I am Legion) in an opposite sense, And not by show of hands decide between The multiple factions which my state has seen Or will see. Condescend to the pretence That what speaks now is $\mathrm{I}$; in its defence Dissolve my parliament and intervene.

Thou wilt not, though we asked it, quite recall Free will once given. Yet to this moment's choice Give unfair weight. Hold me to this. Oh strain A point - use legal fictions; for if all My quarrelling selves must bear an equal voice, Farewell, thou hast created me in vain.

(Lewis, 1964:119) 
The speaker draws attention to the many conflicting "voices" or desires within himself, firstly by the reference to his "present voice", which implies that there are others. His assertion that he is "Legion" reinforces this concept, as it is an allusion to Jesus' healing of the man who was possessed by many unclean spirits (Mark 5:1-20 and Luke 8:26-36).

The poet employs an extended image which is very like a metaphysical conceit in order to sustain the concept of the plurality of the self experienced by the speaker. He likens himself to a "state" or kingdom, and suggests that within himself there are "multiple factions", which will continue to exist without reaching consensus. Ironically, he pleads that the democratic practice of a "show of hands", implying equality on the part of many voters, should not be used to decide his fate. This suggests that his present state of mind is of equal status to the others that he experiences, although it may express a contrary stance to them. He expresses his realization that his present voice is only a "pretence", as he perceives that by nature he is unable to remain constant. The plea that God should "condescend" reflects the speaker's realization that God is far removed from him, and exists on a totally different plane. He begs that God should take the "pretence" of his present utterance and accept it as the truth. This may be done by God's direct intervention in dissolving his "parliament" of varying emotions and standpoints.

Apart from the Biblical allusion to Legion, the image of state in the work echoes such Shakespearean sonnets as "When to the sessions of sweet silent thought" (Hollander \& Kermode, 1973:429-430), which uses a legal conceit to convey the thoughts of the poet. The Renaissance evocation is sustained in the speaker's assertion: "Thou wilt not, though we asked it, quite recall/Free will once given", in that the doctrine of predestination versus free will was being hotly debated at that time. The assertion that God will not "quite recall" "free will once given" voices the speaker's acceptance of the doctrine of humankind's responsibility before God.

The metaphor of statecraft is extended in lines $10 \mathrm{~b}$ to 14 . Aware of the fact that his many "selves" have equal status in the "parliament" of his being, the speaker asks God to take his present "choice" and make it more binding than his other choices. He employs the statecraft image to do this by using the terms "give unfair weight" and "strain a point". The reader is left to infer that the speaker has made a "choice" to serve or worship God, and it is this "choice", echoing the predestination/free will debate, that he wishes to prevail over all the other options that arise within himself. The concept of diverse voices within the speaker which are clamouring to be heard is reiterated when he refers to his "quarrelling selves" and emphasizes that he finds no harmony or unity within himself. The speaker asserts that if God does not give "unfair weight" to his "choice" in favour of God, he will have been "created in vain". The Westminster 
Shorter Catechism, penned in the seventeenth century, begins with the question "[w]hat is the chief end of man?", to which the reply is: "[m]an's chief end is to glorify God and enjoy him for ever" (Cross \& Livingstone, 1997:1732). The speaker is thus suggesting that if God does not make his present "choice" binding, he will not fulfil the purpose for which he was created, namely, to "glorify God and enjoy him for ever".

There is also a resonance here of St. Ignatius's first principle and foundation expressed in his Spiritual Exercises, which contains the statement: "[m]an is created to praise, reverence, and serve God our Lord, and by this means to save his soul" (Puhl, 1951:12). The speaker therefore asks God to overrule and transcend his vacillation, and differing "voices" and "selves", in order that his soul may be saved. A paradox is apparent, as the speaker previously referred to his belief that God does not retract man's "free will", and yet, in the closing lines of the sonnet, he requests God to overrrule his other democratic "choices" in order that his "choice" in God's favour may stand. The poem may also be seen to echo Donne's ambivalence towards God which is given paradoxical expression in the sonnet "Batter my heart, three-personed God ..." (Hollander \& Kermode, 1973:552).

The allusion to Jesus' encounter with "Legion" earlier in the sonnet conveys the poet's conviction that he needs to be delivered from the many "selves" and "voices" within his being, just as the man in the story was delivered from the unclean spirits. The parallel also suggests that Christ is the one who is able to achieve harmony and unity within the "self" of the individual. The last line of the sonnet is surprising in its finality: "Farewell, thou hast created me in vain", and implies that man will not achieve his potential of having fellowship with God if his free will is not overruled in order to bring his being into a state of unity.

It may be said that Lewis sustains the Renaissance ambience of the poem by the careful interweaving of extended metaphor, Biblical allusion, echoes of Shakespearean sonnets and reference to certain religious issues that were being debated at that time. The use of the archaic "thou" in reference to God reinforces this mood. The overall effect conveyed through the feelings expressed in the poem, though, is timeless: the speaker longs for harmony within himself, which he realizes is only possible if God, who in the Trinity embodies ultimate Unity, transcends his many "voices" in order to accomplish such oneness.

\section{5. "Prayer"}

The lyric entitled "Prayer" is simpler in style than "Legion" but it embodies similar sentiments, in that the speaker voices an utter dependence on God. However, the speaker concentrates in this case on his dependence on God regarding prayer. A conversational style is sustained throughout, which provides a con- 
temporary feel to the work. The sixteenth and seventeenth century conventions and allusions have been discarded in order to express the speaker's present difficulties in his prayers. He addresses his "Master":

Master, they say that when I seem

To be in speech with you,

Since you make no replies, it's all a dream

One talker aping two.

They are half right, but not as they

Imagine; rather, I

Seek in myself the things I meant to say,

And lo! the wells are dry.

Then, seeing me empty, you forsake

The Listener's role, and through

My dead lips breathe and into utterance wake

The thoughts I never knew.

And thus you neither need reply

Nor can; thus, while we seem

Two talking, thou art One forever, and I

No dreamer but thy dream.

(Lewis, 1964:122-23)

A sense of respect is conveyed by the use of the term "Master", and the fact that the speaker's accusers are not identified, but are merely referred to as "they", creates an uneasy atmosphere in that the accusers lack definition and seem nebulous. The verb "seem" initially points to the fact that "they" are not convinced of the objective reality of his "speech" with his "Master", thus calling into question the validity of his prayer. The speaker then progresses to deal with one of the most difficult problems related to prayer: the person praying is often uncertain about the "replies" he may receive. The simplicity of diction in the first stanza contrasts sharply with the complexity of the speaker's problem.

He is not tentative about the difficulty he encounters. He boldly asserts that "no replies" are made, and therefore "they" consider that his whole experience of prayer is a "dream", which conveys their view of its subjective nature and suggests that it is a figment of his imagination. The scoffmg nature of the accusations against the speaker's prayer is underlined by the use of the verb "aping", which echoes Lewis's image of an ape to suggest the counterfeit in his poem "Sweet Desire". The speaker's detractors insist that when he prays, his imagination conjures up the other party involved, with the result that "[o]ne talker" is "aping two".

In the second stanza the speaker concedes that "they" are "half-right", but he neatly reverses the position by asserting that it is "they" who are using their 
imaginations. The locus of reality has thus changed: the accusers insist that the speaker is imagining a listener to his prayers, whereas he maintains that it is they who are dealing in unreality. The reversal is stressed by the use of the semicolon in the second line of the stanza, which causes a caesura, followed by the words "rather, I". The speaker goes on to reveal how he reaches into himself to find material for his prayers, "the things I meant to say", but finds that "the wells are dry". The image of aridity is particularly apt because it encapsulates the feelings expressed in the poem "The Naked Seed", and summarizes the Biblical allusions to water which Lewis inverted in that work to underline his spiritual dryness and deadness.

The image of "wells" which are "dry" is reinforced by the speaker's recognition that he is "empty". He perceives that in this state of emptiness, because he is unable to pray, God "forsake[s]/The Listener's role", and "breathes" new "thoughts" into his mind. The phrase "[t]he Listener's role" implies passivity on God's part, which is in sharp contrast to the divine activity portrayed in the concept that God "breathes" through the speaker's "dead lips" and enables him to give expression to "thoughts [he] never knew". There is an allusion here to Genesis 2:7 which states: "And the Lord God formed man of the dust of the ground, and breathed into his nostrils the breath of life; and man became a living soul" (KJV). The allusion sustains the perception of God as the active agent who bestows life, and the anthropomorphic concept of God "breathing" is suggestive of the activity of the Holy Spirit mentioned by Jesus in John $3: 8$, while it also echoes certain Old Testament images.

The speaker advances his argument with the assertion that, because God is the author of all his thoughts and prayers, He does not "need" to reply, "[n]or can". This is an echo of the doctrine of God's self-sufficiency and transcendence which was touched on in the final lines of the poem entitled "The Naked Seed". The term "thus" is used to introduce the conclusion at which he has arrived: the speaker and God appear to be "Two talking", as evoked by the verb "seem", whereas in fact the Deity is "One forever". This conviction is stressed by a shift in mood, achieved by the use of the archaic "thou", in contrast to the more contemporary "you" in the earlier stanzas of the poem.

The lyric draws to a surprising close when the speaker asserts that he is "[n]o dreamer, but thy dream". Paradoxically, the objectivity of the speaker's existence lies in the fact that he is the subject or God's thought or "dream". He is here positing that, contrary to what his accusers may say, he exists only because he is the result of God's creative act, the breathing of life into him through the agency of the Holy Spirit. The fact that the speaker perceives himself to be God's "dream" suggests that he has transcended his notions of self-sufficiency. This act has brought him to the realization that he is the "dream" or creation of the "One forever", which is a reference to the unity of the 
Trinity. In his autobiography, Surprised by Joy, Lewis (1977:177) succinctly mirrors the essence of the thought expressed in the poem "Prayer":

[w]e mortals, seen as the sciences see us and as we commonly see one another, are mere 'appearances'. But appearances of the Absolute. In so far as we really are at all (which isn't saying much) we have, so to speak, a root in the Absolute, which is the utter reality. And that is why we experience Joy: we yearn, rightly, for that unity which we can never reach except by ceasing to be the separate phenomenal beings called 'we'. Joy was not a deception. Its visitations were rather the moments of clearest consciousness we had when we became aware of our fragmentary and phantasmal nature and ached for that impossible reunion which would annihilate us or that self-contradictory waking which would reveal, not that we had had, but that we were, a dream.

However, this was Lewis's opinion at the time he was converted to theism, hence such terms as "impossible reunion", "annihilation" and "selfcontradictory". In his later work, The Problem of Pain, he explains his concept of union with God in the following terms (1977a:138-139):

[f]or union exists only between distincts; and, perhaps, from this point of view, we catch a momentary glimpse of the meaning of all things. Pantheism is a creed not so much false as hopelessly behind the times. Once, before creation, it would have been true to say that everything was God. But God created: He caused things to be other than Himself that, being distinct, they might learn to love Him, and achieve union instead of mere sameness. Thus $\mathrm{He}$ also cast His bread upon the waters. Even within the creation we might say that inanimate matter, which has no will, is one with God in a sense in which men are not. But it is not God's purpose that we should go back into that old identity (as, perhaps, some Pagan mystics would have us do) but that we should go on to the maximum distinctness, there to be reunited with Him in a higher fashion. Even within the Holy One Himself, it is not sufficient that the Word should be God, it must also be with God. The Father eternally begets the Son and the Holy Ghost proceeds.

Lewis's mature Christian vision, in which self-sufficiency is transcended in the realization that one really exists only insofar as one is the creation of the Trinity or "One forever", is encapsulated in the poem entitled "Prayer". The work was described by Griffin (1986:152) as being "about the dynamics of prayer", but a close examination of it shows how, in the space of sixteen lines, Lewis has not only refuted the arguments of the speaker's accusers, but has also drawn together and compressed into the unity of the poem the temper and thought of some of his earlier works along with Biblical allusions and concepts. However, it would appear that, the closer Lewis drew to an apprehension of the unity of the Trinity, the less he relied on extraneous ideas and sources. The spareness of expression and simplicity of diction in "Prayer" reflects his singleness of purpose in its composition, without sacrificing the intensely personal register. 
While other poems in the collection also reveal his considered religious viewpoint, "Prayer" eloquently expresses the most important concept expressed in the poetry, namely, that all diversity finds its ultimate resolution in the loving and reciprocal relationship of unity that exists in the Christian concept of the Trinity.

\section{Conclusion}

This article has sought to explore certain of Lewis's poems and chart the difficulties regarding faith that he expressed through the medium of his overtly Christian poetry. These difficulties concern the struggle for an intellectually muscular faith which takes cognizance of doubt and uncertainty as well as weakness and a reticence to embrace the God of Christianity. It has been suggested that the speaker finds resolution in the fact that, although God stands over and above humankind, He understands their frailty and transcends it by providing an apprehension of the loving and reciprocal relationship of unity that prevails in the Trinity. In spite of the wide diversity of genres embodied in Lewis's writing, it would appear that his devotional poetry expresses more explicitly than any of the other forms in which he wrote his longing to explore the Ultimate Reality that he believed is embodied in the Trinity, notwithstanding his own difficulties concerning faith and belief. It is suggested that it is the timeless desire to plumb the depths of Reality with integrity which informs and gives unity to the body of his writing as a whole, and which continues to make his work relevant in contemporary society, one hundred years after his birth.

\section{Bibliography}

Anderson, S. (ed.) 1996. The Virago Book of Spirituality: Of Women and Angels. London : Virago Press.

Cross, F.L. \& Livingstone, E.A. (eds.) 1997. The Oxford Dictionary of the Christian Church Oxford : Oxford University Press.

Eliot, T.S. 1974. Collected Poems. London : Faber and Faber.

Griffin, H.W. 1986. C.S. Lewis: The Authentic Voice. Tring (Herts.) : Lion Publishing.

Hollander, J. \& Kermode, F. (eds.) 1973. The Literature of Renaissance England. London : Oxford University Press.

Hopkins, G.M. 1953. Poems and Prose. (ed.) W.H. Gardner. Harmondsworth : Penguin.

Lewis, C.S. 1938 [1952]. Out of the Silent Planet. London: John Lane (the Bodley Head); London : Pan Books

Lewis, C.S. 1943. [1953]. Perelandra (Voyage to Vemus). London : John Lane (the Bodley Head), London : Pan Books.

Lewis, C.S. 1945. [1983]. That Hideous Strength: A Modern Fairy-Tale for Grown-Ups. London: John Lane (the Bodley Head); London : Pan Books.

Lewis, C.S. 1950. [1980]. The Lion, The Witch and the Wardrobe. London: Geoffrey Bles; Harmondsworth : Penguin Books

Lewis, C.S 1956. [1978]. Till We Have Faces: A Myth Retold. London : Geoffrey Bles; London : Collins Fount.

Lewis, C.S. 1961. A Grief Observed. London : Faber and Faber. 
Lewis, C.S. 1964. Poems. W. Hooper (ed.) London : Geoffrey Bles.

Lewis, C.S. 1970. God in the Dock: Essays on Theology and Ethics. W. Hooper (ed.) Grand Rapids : Eerdmans.

Lewis, C.S. 1977. Surprised by Joy. Glasgow : Collins.

Lewis, C.S. 1977a. The Problem of Pain. Glasgow : Collins.

Puhl, L.J. 1951. The Spiritual Exercises of St. Ignatius Chicago : Loyola University Press.

Secker, J.E. 1982. Consolatory Literature of the English Recusants. Renaissance et Reforme, $18(2): 122-141$ 